\title{
Copper (Cu) an Essential Redox-Active Transition Metal in Living System- A Review Article
}

\author{
Syed Khalid Mustafa*, Meshari Ahmed AlSharif \\ Department of Chemistry, Faculty of Science, University of Tabuk, Tabuk, KSA \\ Email: *khalid.mustafa938@gmail.com, me_2500@hotmail.com
}

How to cite this paper: Mustafa, S.K. and AlSharif, M.A. (2018) Copper (Cu) an Essential Redox-Active Transition Metal in Living System-A Review Article. American Journal of Analytical Chemistry, 9, 15-26. https://doi.org/10.4236/ajac.2018.91002

Received: November 20, 2017

Accepted: January 8, 2018

Published: January 11, 2018

Copyright (c) 2018 by authors and Scientific Research Publishing Inc. This work is licensed under the Creative Commons Attribution International License (CC BY 4.0).

http://creativecommons.org/licenses/by/4.0/

\section{(c) (i) Open Access}

\begin{abstract}
In this review article, an attempt has been made for the study of copper, an essential Redox-Active transition metal in living systems. Very least amount of Copper is recognized as a constituent of living system. Detection and estimation of Copper in various living systems have been done and reported by various workers time to time. The presence of Copper is reported more or less in all forms of life. The reported data of work done so far details are available everywhere. This review work is concentrated on its significance of the presence of optimum amount of Copper in living systems. The required particular amount of copper in physiological cycle results thriving, whereas the deviated amount of copper leads to menace in living system, this deviation from the optimum amount makes unhealthy and creates an abnormal condition of metabolic activities in the living systems. This work is totally based on the reports examined the effect of Copper on cellular cycle till today.
\end{abstract}

\section{Keywords}

Copper, Bio-Molecules, Haemocyanin, Phytoremediation, Antioxidant, Toxic

\section{Introduction}

Copper is a transition metal or a d-block element. It is a member of Group-1B in periodic table with Silver $(\mathrm{Ag})$ and Gold $(\mathrm{Au})$. Its electronic configuration is $3 \mathrm{~d}^{10} 4 \mathrm{~s}^{1}$. Mainly it is found in America at Superior, Ural Mountain in Siberia, Assam and (Singhbhum), Jharkhand State of India. There are three important oxidation states of copper $(\mathrm{Cu})$ that are zero $(0)$ (pure Metal), +1 ous-suffix added compounds, +2 ic-suffix added compounds. Its important ores are Malachite $\left\{\mathrm{CuCO}_{3} \cdot \mathrm{Cu}(\mathrm{OH})_{2}\right\}$, Azurite $2\left\{\mathrm{CuCO}_{3} \cdot \mathrm{Cu}(\mathrm{OH})_{2}\right\}$, Chalcocite or Copper glance 
$\left(\mathrm{Cu}_{2} \mathrm{~S}\right)$, Copper Pyrites $(\mathrm{Cu} \mathrm{FeS})\left(\mathrm{Cu}_{2} \mathrm{~S} \cdot \mathrm{Fe}_{2} \mathrm{~S}_{2}\right)$. Copper $(\mathrm{Cu})$ may be $\mathrm{Cu}^{1+}$ or $\mathrm{Cu}^{2+}$ in ionic state and known as -ous and -ic suffix, forms Complexes with suitable ions and radicals. Copper $(\mathrm{Cu})$ occupies $\mathrm{d}^{9}$-state in various complexes. Moist air affects Copper $(\mathrm{Cu})$ and makes green coating of $\mathrm{CuSO}_{4} \cdot 3 \mathrm{Cu}(\mathrm{OH})_{2}$, it is a basic sulphate, which is dissolved in concentrated acids. The Copper $(\mathrm{Cu})$ is essential to life, it is the third most abundant trace element in the body after zinc and iron, but whenever the amount $80,000 \mu \mathrm{g}$ to $100,000 \mu \mathrm{g}$ of copper intakes by an adult human body from the outsource, becomes toxic. Excess of copper leads to damage the antioxidant enzyme function, oxidative modification of DNA and proteins, lipid oxidation, activate the redox-sensitive genes, suppress the Zinc consumption in the body and also makes anemic by interfering with iron transport. Only 4000 - $5000 \mu \mathrm{g}$ of Copper $(\mathrm{Cu})$ is required daily in normal diet for an adult [1] [2] [3] [4] [5]. One can see the lower and higher intake level for Copper ( $\mu \mathrm{g} /$ day) in male and female for various age groups in Table 1, as per regulation of Food and Nutrition Board, Institute of Medicine, D.C. Washington, National Academy Press [2].

Copper's deficiency results in the incapability to use Iron (Fe) which is stored in the Liver and makes anaemic. Pure iron (Fe) does not be effective in glucose utilization. Copper $(\mathrm{Cu})$ helps in conversion of dietary $\mathrm{Fe}$ (iron) into Hemoglobin. Copper deficiency causes oxidative stress which is a disturbance in the balance between the oxidant and antioxidant defenses. This imbalances are created either by the excess formation of oxidant or free radicals or by the deficiency in the antioxidant defenses, this leads to inactivation of NO, oxidative modification of DNA and proteins, lipid oxidation and activation of redox-sensitive genes. Physiology and metabolism of Copper $(\mathrm{Cu})$ are associated with metalloproteinase, Vitamin-C and various oxidases like amino oxidase, ascorbate oxidase, cytochrome oxidase, Galactose oxidase, Lysine oxidase, Dopamine Hydroxylase, Tyrosinase. It plays vital role with antioxidant, enzyme, super oxidase and dismutase.

Table 1. Recommended Dietary Allowance (RDA) for Copper for various age groups in male and female.

\begin{tabular}{|c|c|c|}
\hline Age Group & $\begin{array}{l}\text { Males/Females-Lower Intake } \\
\text { Level for Copper ( } \mu \mathrm{g} / \text { day) }\end{array}$ & $\begin{array}{l}\text { Males/Females-Upper Intake } \\
\text { Level for Copper ( } \mu \mathrm{g} / \text { day) }\end{array}$ \\
\hline $0-6$ months & $200(\mathrm{AI})$ & Not possible to establish ${ }^{*}$ \\
\hline $7-12$ months & $220(\mathrm{AI})$ & Not possible to establish ${ }^{*}$ \\
\hline $1-3$ years & 340 & 1000 \\
\hline $4-8$ years & 440 & 3000 \\
\hline $9-13$ years & 700 & 5000 \\
\hline $14-18$ years & 890 & 8000 \\
\hline 19 years and older & 900 & 10,000 \\
\hline All ages & - & - \\
\hline All ages & - & - \\
\hline
\end{tabular}

*Source of intake should be from food and formula only. 
The Copper $(\mathrm{Cu})$ is present in every tissue of the body, but is stored basically in the liver but in smaller amounts found in the brain, heart, kidney, and muscles.

Copper can act as both an anti-oxidant and a pro-oxidant. Copper plays an important role in human metabolism, largely because it allows many fundamental and essential enzymes to function properly and also plays a role in the production of hemoglobin, myelin, and melanin. Not only it's essential roles as structural and metabolic cofactors for bio molecules. Copper is playing an important role as transition metal signaling, transferring information in and beyond the brain, between and within the living cells. Some significant evidences were found that a physiological imbalance of the redox-active bio metals, $\mathrm{Cu}$ and $\mathrm{Fe}$, and oxidative stress lead to the neuropathology of Alzheimer's disease. The Menkes syndrome and Wilson disease are also due to the severe copper deficiency and severe copper toxicity, respectively [1] [5]-[18].

The total amount of Copper $(\mathrm{Cu})$ present in the whole plant is $2.75 \mathrm{ppm}$. It is a toxic metal in larger amount. Its deficiency causes deformation and Chlorosis in leaves followed by narcosis of the tips of young leaves and affects the reproductive organs of plants also. Copper involved in many physiological processes in plants. Because it is a redox-active transition metal exist in different oxidation-state from 0 to +2 acts as a basic element to takes-part in photosynthesis, electron transport, mitochondrial respiration and regulatory proteins. High concentration of copper is highly toxic, because of the redox property of copper catalyze the production of toxic hydroxyl group $\left({ }^{-} \mathrm{OH}\right)$ which damage the lipids, proteins and other bio molecules. So the concentration of copper should be maintained at low level. Therefore the copper acts as basic essential micronutrients for the proper growth and development of plants. Copper $(\mathrm{Cu})$ containing compounds are associated with chloroplasts of green plants which act as an electron carrier in photosynthesis. Plastocyanin and Azurin are found in chloroplasts of green plants which act as an electoral carrier in photosynthesis. Azurin is found in bacteria and structurally similar Plastocyanin. Molluscs and shellfish are rich source of Copper. Betel leaves, areca nut, some other nuts, walnut, cashew nut, coconut almond ground nut, oranges, green grapes, papaya are the sources of Copper $(\mathrm{Cu})$ in Plant groups, which are used for good health [19]-[25].

According to the various observations and statements under discussion were published on single-species that show their inability to test for the effects of Copper $(\mathrm{Cu})$ with different concentrations on interacting species in the different field conditions. This may have indirect effects on organisms due to changes in the affluence of individual species that act as cohabitate. In vast ocean where copper causes certain changes in the composition of different organisms in the different field conditions, the effects on mobile invertebrates associated with these habitats, however, are still unknown. It was tested the effects of copper on the association of different invertebrates that colonized infield conditions, and demonstrated strong changes in the composition of interacting mobile taxa. Due 
to the presence of copper it can be estimated. Manipulative field experiments partitioned the direct effects of copper from possible indirect effects mediated through changes to their marine habitat. Some other organisms were selectively gardened in the absence of copper for normal estimation and again it exposed by different concentrations of copper. The assemblages of mobile invertebrates varied between manipulated habitats, indicating that copper can indirectly affect mobile fauna via habitat change. The mechanisms of these effects were then examined with artificial habitats that resemble the physical structure of polluted and unpolluted by different Copper $(\mathrm{Cu})$ concentrations. The compositions of the mobile fauna were again dependent on the particular habitat. In both experiments, there were interactions between the effect of habitat and the presence of copper, demonstrating the need for multi-species, field experiments to totally identify the effects of copper in natural conditions and manipulative field conditions as well [21] [24]-[29].

Similarly another thought on analyzing complex cellular processes requires the ability to track bio molecules as they function within their native habitat. Although genetically encoded characters with discrete proteins, they can cause significant for a particular protein's structure and have no direct extension to other classes of bio molecules such as glycan lipids, nucleic acids and secondary metabolites. In recent years, an alternative and more effective tool for interacting bio molecules has emerged from the chemical biology community of the biochemical reporter. In a prototypical experiment, a unique chemical group appeared, often as small as a single functional group, is incorporated into the target bio molecule using the cell's own biosynthetic machinery. The chemical reporter modified in a highly selective fashion with an extrinsic delivered functional group associated with copper. This review highlights the development of bio chemical reporters, reactions and their applications in living systems [21] [30][34].

\section{Observations}

On the basis of visual observation of various laboratories reports published time to time. The comparative studies were done frequently and the results were recorded. Although the experiments were performed completely different ways but results were found almost more or less similar, which shows that the optimum availability of the presence of copper in living system. Recent studies with molecular insulin-mimetic copper action have confirmed that copper ions strongly activate phosphoinositide-3-kinase, which accelerate the metabolic processes in the cell. Copper is known to stimulate the glycine synthesis, so its deficiency brings effect glycine synthesis. Like insulin-copper effects on carbohydrate metabolism have been noted in rats fed allow-copper diet which reduce body weight due to less carbohydrate utilization as energy source under resting conditions. Positive and significant correlation has been noted between plasma and copper levels. Despite that until now copper supplements are not recommended 
due to the lack of reliable indices of marginal copper deficiency. Copper deficiency cause many diseases arterial hypertension, hypercholesterolemia, diabetes, Alzheimer. On the other hand, excess of copper is extremely harmful, adversely affecting iron level, lipoprotein metabolism and antioxidant protection [4] [6] [10] [35]-[41].

In another situation all heavy metals, including those that are essential micronutrients are copper, zinc, Iron etc. are toxic to algae at high concentrations. One characteristic feature of heavy-metal toxicity is the poisoning and inactivation of enzyme systems metabolic activities of many of the physiological phenomenon as well as biochemical processes like photosynthesis, respiration, protein synthesis and chlorophyll synthesis etc. are severely affected at high metal concentrations, in on with living systems [21] [24] [25]. Some algae inhabit waters extremely polluted with heavy-metal-laden wastes from mining and smelting operations; nodularia sp. oscillatoria sp. cladophora sp. Hydrodictyon sp. etc. occur in metal-rich waters. These algal forms are probably more capable of counter the toxic levels of heavy metals and this feature is a result of physiologi$\mathrm{cal}$ and genetic adaptations. The sensitivity or tolerance to heavy metals varies amongst different algae. The phenomena of multiple tolerance and co-tolerance may be exhibited by some algae. Heavy-metal pollution causes reduction in species diversity leading to the dominance of a few tolerant algal forms. The primary productivity also decreases after metal supplementation. The uptake and accumulation of heavy metals can be active (energy-dependent), passive (energyindependent), or both. Heavy metals can be safely stored as intra nuclear complexes by some algae. Notwithstanding this, some changes in the cell wall can enable the algae to tolerate heavy metals by checking the entry of the metals. The metal content of algae growing in a water body may yield valuable information for simulating heavy metal pollution: several species of members of Chlorophyceae have been extensively used for these types of observations. Several factors affect and determine toxicity of heavy metals to the algal flora. At low $\mathrm{pH}$, the availability of heavy metals to algae is greatly increased, as a consequence of which pronounced toxicity is evident. Hard waters decrease metal toxicity. Some ions, of heavy metals can alleviate toxicity of metals in the living systems. The presence of other metals can influence toxicity of a heavy metal through simple additive effect or by synergistic and antagonistic interactions. Similarly, other pollutants can influence heavy-metal toxicity. The toxicity of heavy metals depends upon the natural condition because of their various ionic forms of a metal characterized by different valence states may be differentially toxic to a particular alga. Amino acids and other organic matters can create complex with heavy metals and make them unreachable. This may eventually lead to less toxicity. Heavy-metal toxicity largely depends upon algal population density. The denser populations of more numerous cellular available sites are leading to decreased toxicity. The tolerance to copper ions on Skeletonemacostatum (Grev.), Thalassiosira Pseudonana (Hust.) and Phaeodactylumtricornutum (Bohlin) grown in 
dialysis and batch cultures in the total water has been established. Reduction of growth rates were observed by the addition of different amount of copper ions respectively for different species. At the higher levels of copper addition (400 and $700 \mu \mathrm{g} / \mathrm{L}$ ) to the cells of ppm. tricornutum in dialysis culture increased their copper content to more than 200 times over those of the controls, the ratio of copper to chlorophyll in the cells increasing 150 times.

Many of the scientist of this fields selected algae for their experimental work due to its easy availability and the low expenditure. The 8th international conference on algal biomass, bio fuels and bio products provides an exciting venue to learn about the latest research and technologies in all area of algal research and to interact with the scholars of this field. Emphasis will be placed on the latest unpublished technical and scientific results, along with discussions and direct or indirect interactions with the international community.

Algal harvesting and extraction systems show metallic activity in algal breeds and propagation. New conversion technologies for Algal bio fuels, including catalytic, thermal, and enzymatic systems are utilized for micro-analysis of metallic particles. A bio product from algal material including high-value products and co-products supports the observation of presence of copper. Life cycle of algal flora is almost dependent upon metal ions. New technologies in support of algal researches in the areas of separation, refining, detection, characterization and analysis also favor the heavy metal activities. Various results shows marked increase in copper content when a copper salt was added to batch cultures to the algal material. Skeletonemacostatum found nearly identical sensitivity to copper ions, but they differed markedly in their zinc tolerance as well as the comparative study of copper, iron and zinc, presented their bio chemical reporters indifferent living organisms observed and reported by various workers [42]-[60]. Where, one of the most impressive applications of protein fusions has been remarkable imaging of protein expression and localization in living organisms. Chemical reporters might provide similar opportunities for other classes of bio molecules. Already, both proteins and glycan are also influenced by metallic ions. The demands on bio reactions in this context are far more exacting than those for cellular systems. Apart from having extraordinary chemical selectivity, the reagents must not be liable to rapid metabolic breakdown or excretion, and they must not accumulate in cells or organs non-specifically on the timescale of the reaction. The chemical reactions that do not interfere with cellular processes are important in the investigation of biological functions. The complex formation between copper ions and bio molecules are not biocompatible because coppers used as catalyst are toxic. Recently a new nontoxic catalyst makes this reaction biocompatible. This new developed catalyst, having nano-particles of copper bound into a polymer resin. The copper-catalyzed azide-alkyne cycloaddition (CuAAC) reaction have wide applications in the study of biological functions as well as limiting the toxicity of copper ions [61]-[71]. Now living organism needs a little more attention of heavy metals chemistry. 


\section{Discussions and Remarks}

Turnlund J.R. et al. [4] [5] worked on Long-term high copper intake: effects on indexes of copper status, antioxidant status, and immune function in young men in the year (2004) and also they continue studied some effects on copper absorption, retention, and homeostasis in living systems (2005). Various workers [6]-[40] find out many noticeable and remarkable results for different transition metals, on human living systems, plants, vegetables, crops and marine. By taking account of the above mentioned literature [3] [4] [5] [10]-[25], we have studied the importance of Copper $(\mathrm{Cu})$ metal on the living system and our findings with review were found in good agreement with other workers [1]-[10] [30]-[71].

The basic challenge is to know:

1) How copper affect the physiological process of the living system.

2) How to ensure the adequate supply to avoid deficiency.

3) How to prevent the accumulation to toxic levels.

On the other hand, a simple and convenient approach of the bio chemical reporter to study and visualize different classes of bio molecules in living systems. The substrates complexed with chemical reporters can be metabolized by cells and integrated with proteins, glycan, lipids and other cellular species. After detection and identification of these bio molecules make sure it's presence in living cells and, in some cases, in the living organisms. By using this methodology bio molecules and biopolymers can be tracked in their native habitats. Apart from this scientist facing many challenges in biological system, one is due to metabolic labeling and second due to chemical tagging in biological system. Addition of a chemical reporter to a bio molecule in living organism affects the biological activity and stability of the proteins, lipids, glycan and other cellular species. Second thing rapid reactions are essential for the observation of biological events that should occur on a very short time scale or with the bio molecules of low amount. The slow rates of reaction cripple the use of bio reactions for bio molecules tagging.

This problem might be solved by understanding the interaction of heavy transition metals such as copper, iron and zinc with the biomolecules as well as, reversible association with adjoining components. It is clear that chemical reporters and bio reactions have a rich prospect in the field of bio chemistry and synthetic chemistry, including the controlled metabolic labeling with the reporter and biotransformation in the living organisms, especially after the development of the new techniques and methodology for the tracking of bio molecules and biopolymers.

\section{Conclusion}

The copper, an essential Redox-Active transition metal acts as basic and essential micronutrients for the growth and development of the living system. The excess amount of Copper found hazardous whereas the lesser amount caused deficiency. Therefore, the optimum limit of Copper for a particular species of living sys- 
tem was found effectual. In the case of human being, the proper dose of Copper should be provided and must be supplemented for the betterment and the future of betterment of human society. The mineral nutrition of plants world is of fundamental importance to agriculture and human health needs to ensure an effective and proper supply of copper to counter it's deficiency for the healthy growth and development. Comparison of various heavy metals in their natural concentrations in seawater implies that cadmium is not only an important ecological factor in unpolluted waters, but natural copper concentrations inhibit the reproduction of some phytoplankton species and particularly cyanobacteria, in seawater. Copper also influences the seasonal succession of various species. Afore mentioned species have shown marked increased in copper content when a copper salt was added to bio-tech cultures of the algae, it showed sensitivity to copper ions but they differed markedly in their zinc and other transition metals tolerance.

\section{Acknowledgements}

The authors would like to acknowledge the keen support for this work of the Department of Chemistry, Faculty of Science, University of Tabuk, Saudi Arabia [72] [73].

\section{References}

[1] Singh, M.R. (2007) Impurities-Heavy Metals: IR Prespective. http://www.usp.org/pdf/EN/meetings/asMeetingIndia/2008Session4track1.pdf

[2] Institute of Medicine (2001) Food and Nutrition Board. Dietary Reference Intakes for Vitamin A, Vitamin K, Arsenic, Boron, Chromium, Copper, Iodine, Iron, Manganese, Molybdenum, Nickel, Silicon, Vanadium, and Zinc. National Academy Press, Washington DC, 224-257.

[3] Sadhra, S., Wheatley, A.D. and Cross, H.J. (2007) Dietary Exposure to Copper in the European Union and Its Assessment for EU Regulatory Risk Assessment. Science of the Total Environment, 374, 223-234. https://doi.org/10.1016/j.scitotenv.2006.12.041

[4] Turnlund, J.R., Jacob, R.A., Keen, C.L., et al. (2004) Long-Term High Copper Intake: Effects on Indexes of Copper Status, Antioxidant Status, and Immune Function in Young Men. American Journal Clinical Nutrition, 79, 1037-1044.

[5] Turnlund, J.R., Keyes, W.R., Kim, S.K. and Domek, J.M. (2005) Long-Term High Copper Intake: Effects on Copper Absorption, Retention, and Homeostasis in Men. American Journal Clinical Nutrition, 81, 822-828.

[6] Hambidge, K.M. and Nichols, B.L. (1978) Copper Deficiency in Clinical Medicine; Zinc and Copper in Clinical Medicine. SP Med. Sci. Books, New York, 119-126.

[7] Halliwell, B. and Gutteridge, J.M.C. (1989) Free Radicals in Biology and Medicine. 2nd Edition, Oxford University, Oxford.

[8] Miyawaki, A., Sawano, A. and Kogure, T. (2003) Lighting up Cells: Labeling Proteins with Fluorophores. Nat. Cell Biol., 5, S1-S7.

[9] Massoud, T.F. and Gambhir, S.S. (2003) Molecular Imaging in Living Subjects: Seeing Fundamental Biological Processes in a New Light. Genes \& Development, 17, 545-580. https://doi.org/10.1101/gad.1047403 
[10] Stem, et al. (2007) Copper and Human Health: Biochemistry, Genetics, and Strategies for Modeling Dose-Response Relationships. Journal of Toxicology and Environmental Health, Part B, 10, 157-222. https://doi.org/10.1080/10937400600755911

[11] Danks, D.M. (1988) Copper Deficiency in Humans. Annual Review of Nutrition, 8, 235-257. https://doi.org/10.1146/annurev.nu.08.070188.001315

[12] Klevay, L.M. (1980) The Influence of Copper and Zinc on the Occurrence of Ischemic Heart Disease. Journal of Environmental Pathology and Toxicology, 4, 281-287.

[13] Strain, J.J. (1994) Newer Aspects of Micronutrients in Chronic Disease: Copper. Proceedings of the Nutrition Society, 53, 583-598. https://doi.org/10.1079/PNS19940067

[14] Willis, M.S., Monaghan, S.A., Miller, M.L., McKenna, R.W., Perkins, W.D., et al. (2005) Zinc-Induced Copper Deficiency: A Report of Three Cases Initially Recognized on Bone Marrow Examination. American Journal of Clinical Pathology, 123, 125-131. https://doi.org/10.1309/V6GVYW2QTYD5C5PJ

[15] Kodama, H., et al. (2012) Inherited Copper Transport Disorders: Biochemical Mechanisms, Diagnosis, and Treatment. Current Drug Metabolism, 13, 237-250. https://doi.org/10.2174/138920012799320455

[16] Bailey, R.L., et al. (2011) Dietary Supplement Use Is Associated with Higher Intakes of Minerals from Food Sources. American Journal Clinical Nutrition, 94, 13761381. https://doi.org/10.3945/ajcn.111.020289

[17] Ackermanl, C.M. and Chang, C.J. (2017) Copper Signaling in the Brain and Beyond. Journal of Biological Chemistry. https://doi.org/10.1074/jbc.R117.000176

[18] Brewer, G.J. (2012) Copper Toxicity in Alzheimer's Disease: Cognitive Loss from Ingestion of Inorganic Copper. Journal of Trace Elements in Medicine and Biology, 26, 89-92. https://doi.org/10.1016/j.jtemb.2012.04.019

[19] Ernst, E. (2002) Heavy Metals in Traditional Indian Remedies. European Journal of Clinical Pharmacology, 57, 891-896. https://doi.org/10.1007/s00228-001-0400-y

[20] Saper, R.B. and Kales, S.N. (2004) Heavy Metal Content of Ayurveda Herbal Medicine Products. JAMA, 292, 2868-2873. https://doi.org/10.1007/s00228-001-0400-y

[21] Yadav, S.K. (2010) Heavy Metals Toxicity in Plants: An Overview on the Role of Glutathione and Phytochelatins in Heavy Metal Stress Tolerance of Plants. South African Journal of Botany, 76, 167-179. https://doi.org/10.1016/j.sajb.2009.10.007

[22] Sharma, R.K., Agrawal, M. and Marshall, F.M. (2009) Heavy Metals in Vegetables Collected from Production and Market Sites of a Tropical Urban Area of Indi. Food and Chemical Toxicology, 47, 583-591. https://doi.org/10.1016/j.fct.2008.12.016

[23] Stals, M., Thijssen, E., Vangronsveld, J., Carleer, R., Schreurs, S. and Yperman, J. (2010) Flash Pyrolysis of Heavy Metal Contaminated Biomass from Phytoremediation: Influence of Temperature, Entrained Flow and Wood/Leaves Blended Pyrolysis on the Behavior of Heavy Metals. Journal of Analytical and Applied Pyrolysis, 87, 1-7. https://doi.org/10.1016/j.jaap.2009.09.003

[24] Marschner, H. (2011) Mineral Nutrition of Higher Plants. Academic Press, London.

[25] Raven, J.A., et al. (1999) The Role of Trace Metals in Photosynthesis Transport in $\mathrm{O}_{2}$-Evolving Organism. Photosynthesis Research, 60, 111-150. https://doi.org/10.1023/A:1006282714942

[26] Kavakl, P.A. and Guven, O. (2004) Removal of Concentrated Heavy Metal Ions from Aqueous Solutions Using Polymers with Enriched Amidoxime Groups. Journal of Applied Polymer Science, 93, 1705-1710.

[27] Singh, R.P. and Agrawal, M. (2010) Variations in Heavy Metal Accumulation, 
Growth and Yield of Rice Plants Grown at Different Sewage Sludge Amendment Rates. Ecotoxicology Environmental Safety, 73, 632-641. https://doi.org/10.1016/j.ecoenv.2010.01.020

[28] Vinogradov, A.P. (1953) The Elementary Chemical Composition of Marine Organisms. Translated from the Russian by Efron, J., Setlow, J.K., Sears Foundation for Marine Research, Yale University, New Haven, 647 p.

[29] Das, P., Mukherjee, S. and Sen, R. (2009) Biosurfactant of Marine Origin Exhibiting Heavy Metal Remediation Properties. Bioresource Technology, 100, 4887-4890. https://doi.org/10.1016/j.biortech.2009.05.028

[30] Alberts, B. (2002) Molecular Biology of the Cell. Garland Science, New York. https://doi.org/10.1093/aob/mcg023

[31] Speers, A.E., Adam, G.C. and Cravatt, B.F. (2003) Activity-Based Protein Profiling in Vivo Using a Copper (I)-Catalysedazide-Alkyne [3 + 2] Cycloaddition. Journal of American Chemical Society, 125, 4686-4687. https://doi.org/10.1021/ja034490h

[32] Kolb, H.C. and Sharpless, K.B. (2003) The Growing Impact of Click Chemistry on Drug Discovery. Drug Discovery Today, 8, 1128-1137. https://doi.org/10.1016/S1359-6446(03)02933-7

[33] Chen, I. and Ting, A.Y. (2005) Site-Specific Labeling of Proteins with Small Molecules in Live Cells. Current Opinion in Biotechnology, 16, 35-40. https://doi.org/10.1016/j.copbio.2004.12.003

[34] Kho, Y., et al. (2004) A Tagging-via-Substrate Technology for Detection and Proteomics of Farnesylated Proteins. Proceedings of the National Academy of Sciences, 101, 12479-12484. https://doi.org/10.1073/pnas.0403413101

[35] Speers, A.E. and Cravatt, B.F. (2004) Profiling Enzyme Activities in Vivo Using Click Chemistry Methods. Chemical Biology, 11, 535-546.

https://doi.org/10.1016/j.chembiol.2004.03.012

[36] Hahn, M.E. and Muir, T.W. (2005) Manipulating Proteins with Chemistry: A Cross-Section of Chemical Biology. Trends in Biochemical Sciences, 30, 26-34. https://doi.org/10.1016/j.tibs.2004.10.010

[37] Giriat, I. and Muir, T.W. (2003) Protein Semi-Synthesis in Living Cells. Journal of American Chemical Society, 125, 7180-7181. https://doi.org/10.1021/ja034736i

[38] Luchansky, S.J., et al. (2003) Constructing Azide-Labeled Cell Surfaces Using Polysaccharide Biosynthetic Pathways. Methods in Enzymology, 362, 249-272. https://doi.org/10.1016/S0076-6879(03)01018-8

[39] Beck, M.T. (1978) Prebiotic Coordination Chemistry. In: Sigel, H., Ed., Metal Ions in Biological Systems, Chapter 1, Vol. 7, Dekker, New York.

[40] Huebers, H., Huebers, E., Csiba, E. and Finch, C.A. (1978) Iron Uptake from Rat Plasma Transferrin by Rat Reticulocytes. Journal of Clinical Investigation, 62, 944951. https://doi.org/10.1172/JCI109223

[41] Saxon, E., et al. (2002) Investigating Cellular Metabolism of Synthetic Azido Sugars with the Staudinger Ligation. Journal of American Chemical Society, 124, 14893 14902. https://doi.org/10.1021/ja027748x

[42] Marschner, H. (1995) Mineral Nutrition of Higher Plants. 2nd Edition, Academic Press, London.

[43] Sharma, O.P. (1986) Textbook of Algae. McGraw Hill, New York, 22.

[44] Materassi, T.R. (1992) From Open Ponds to Vertical Alveolar Panels: The Italian Experience in the Development of Reactors for the Mass Cultivation of Phototrophic Microorganisms. Journal of Applied Phycology, 4, 221-231. 
https://doi.org/10.1007/BF02161208

[45] Stewart, I. and Falconer, I.R. (2008) In Oceans and Human Health: Risks and Remedies from the Seas. In: Walsh, P.J., Smith, S.L., Fleming, L.E., Solo-Gabriele, H.M. and Gerwick, W.H., Eds., Cyanobacteria and Cyanobacterial Toxins, Academic Press, Burlington, 271-296.

[46] Williams, A.J. and Lutz, P.L. (1975) The Role of the Haemolymph in the Carbohydrate Metabolism of Carcinusmeanas. Journal of the Marine Biological Association of the United Kingdom, 55, 667-670.

[47] Tsien, R.Y. (1998) The Green Fluorescent Protein. Annual Review of Biochemistry, 67, 509-544.

[48] Wang, Y.H., Lin, S.H. and Juang, R.S. (2003) Removal of Heavy Metal Ions from Aqueous Solutions Using Various Low-Cost Adsorbents. Journal Hazard Material, 102, 291-302. https://doi.org/10.1016/S0304-3894(03)00218-8

[49] Tsekova, K., Todorova, D. and Ganeva, S. (2010) Removal of Heavy Metals from Industrial Wastewater by Free and Immobilized Cells of Aspergillusniger. International Biodeterioration and Biodegradation, 64, 447-451. https://doi.org/10.1016/j.ibiod.2010.05.003

[50] Aisen, P. and Listowsky, I. (1980) Iron Transport and Storage Proteins. Annual Review of Biochemistry, 49, 357-393. https://doi.org/10.1146/annurev.bi.49.070180.002041

[51] Mcintyre, T. (2003) Phytoremediation of Heavy Metals from Soils. Advances in Biochemical Engineering Biotechnology, 78, 97-123. https://doi.org/10.1007/3-540-45991-X_4

[52] Halim, M., Conte, P. and Piccolo, A. (2002) Potential Availability of Heavy Metals to Phytoextraction from Contaminated Soils Induced by Exogenous Humid Substances. Chemosphere, 52, 265-275. https://doi.org/10.1016/S0045-6535(03)00185-1

[53] Nowak, B., Pessl, A., Aschenbrenner, P., Szentannai, P., Mattenberger, H., Rechberger, H.F., et al. (2010) Heavy Metal Removal from Municipal Solid Waste Fly Ash by Chlorination and Thermal Treatment. Journal Hazard Material, 179, 323 331. https://doi.org/10.1016/j.jhazmat.2010.03.008

[54] Weissleder, R. and Ntziachristos, V. (2003) Shedding Light onto Live Molecular Targets. Nature Medicine, 9, 123-128. https://doi.org/10.1038/nm0103-123

[55] Chaignon, V., Sanchez-Neira, I., Herrmann, P., Jaillard, B. and Hinsinger, P. (2003) Copper Bioavailability and Extractability as Related to Chemical Properties of Contaminated Soils from a Vine-Growing Area. Environmental Pollution, 123, 229-238. https://doi.org/10.1016/S0269-7491(02)00374-3

[56] Ginocchio, R., Rodriguez, P.H., Badilla-Ohlbaum, R., Allen, H.E. and Lagos, G.E. (2002) Effect of Soil Copper Content and pH on Copper Uptake of Selected Vegetables Grown under Controlled Conditions. Environmental Toxicology and Chemistry, 21, 1736-1744.

[57] Soellner, M.B., Dickson, K.A., Nilsson, B.L. and Raines, R.T. (2003) Site-Specific Protein Immobilization by Staudinger Ligation. Journal of the American Chemical Society, 125, 11790-11791. https://doi.org/10.1021/ja036712h

[58] Luchansky, S.J., Argade, S., Hayes, B.K. and Bertozzi, C.R. (2002) Metabolic Functionalization of Recombinant Glycoproteins. Biochemistry, 43, 12358-12366. https://doi.org/10.1021/bi049274f

[59] Link, A.J., Mock, M.L. and Tirrell, D.A. (2003) Non-Canonical Amino Acids in Protein Engineering. Current Opinion in Biotechnology, 14, 603-609.

https://doi.org/10.1016/j.copbio.2003.10.011 
[60] Deiters, A., et al. (2003) Adding Amino Acids with Novel Reactivity to the Genetic Code of Saccharomyces cerevisiae. Journal of American Chemical Society, 125, 11782-11783. https://doi.org/10.1021/ja0370037

[61] George, N., Pick, H., Vogel, H., Johnsson, N. and Johnsson, K. (2004) Specific Labeling of Cell Surface Proteins with Chemically Diverse Compounds. Journal of American Chemical Society, 126, 8896-8897. https://doi.org/10.1021/ja048396s

[62] Shaner, N.C., et al. (2004) Improved Monomeric Red, Orange and Yellow Fluorescent Proteins Derived from Discosoma sp. Red Fluorescent Protein. Nature Biotechnology, 22, 1567-1572. https://doi.org/10.1038/nbt1037

[63] Johnsson, N. and Johnsson, K. (2003) A Fusion of Disciplines: Chemical Approaches to Exploit Fusion Proteins for Functional Genomics. Chem. Bio. Chem., 4, 803 810.

[64] Van Swieten, P.F., Leeuwenburgh, M.A., Kessler, B.M. and Overkleeft, H.S. (2005) Bioorthogonal Organic Chemistry in Living Cells: Novel Strategies for Labeling Biomolecules. Organic Bimolecular Chemistry, 3, 20-27. https://doi.org/10.1039/b412558d

[65] Keppler, A., Pick, H., Arrivoli, C., Vogel, H. and Johnsson, K. (2004) Labeling of Fusion Proteins with Synthetic Fluorophores in Live Cells. Proceedings of the National Academy of Sciences, 101, 9955-9959. https://doi.org/10.1073/pnas.0401923101

[66] Dierks, T., et al. (2003) Multiple Sulfatase Deficiency Is Caused by Mutations in the Gene Encoding the Human C $(\alpha)$-Formylglycine Generating Enzyme. Cell, 113, 435 444. https://doi.org/10.1016/S0092-8674(03)00347-7

[67] Rudd, P.M., Elliott, T., Cresswell, P., Wilson, I.A. and Dwek, R.A. (2001) Glycosylation and the Immune System. Science, 291, 2370-2376. https://doi.org/10.1126/science.291.5512.2370

[68] Dube, D.H. and Bertozzi, C.R. (2003) Metabolic Oligosaccharide Engineering as a Tool for Glycobiology. Current Opinion in Chemical Biology, 7, 616-625.

[69] Dundr, M., et al. (2002) A Kinetic Framework for a Mammalian RNA Polymerase in Vivo. Science, 298, 1623-1626. https://doi.org/10.1126/science.1076164

[70] Sadamoto, R., et al. (2004) Control of Bacteria Adhesion by Cell-Wall Engineering. Journal of American Chemical Society, 126, 3755-3761. https://doi.org/10.1021/ja039391i

[71] Clavadetscher, J., et al. (2016) Copper Catalysis in Living Systems and in Situ Drug Synthesis. Angewandtachemie, 55, 15662-15666.

[72] Mustafa, S.K. (2016) Effect of $\mathrm{Ca}\left(\mathrm{H}_{2} \mathrm{PO}_{4}\right)_{2}$ on Azolla. Journal of Harmonized Research Publications, 4, 156-159.

[73] Sarikavakli, N., Mustafa, S.K. and Ahmad, M.A. (2017) Evolution of Thermo-Mechanical Properties of Aluminium-Silicon Alloy (Al-1wt\% Si). American Journal of Materials Synthesis and Processing, 2, 61-64. https://doi.org/10.11648/j.ajmsp.20170205.12 